\title{
THE LIFE AND WORK OF WILLIAM PROUT
}

\author{
by \\ W. H. BROGK
}

He was an example of a man gifted by nature with high intellectual endowments improving those endowments by constant study, investigation, and reflection. An amount of professional labour, such as would have wearied many men, was daily performed by him; and from this he turned for relaxation to arduous chemical and mechanical researches. His mind was of that rare quality which is ever open to the reception of truth, and which steadily pursues that object, undismayed by difficulties, and indifferent alike to ridicule and neglect. ...

NEARLY thirty years after the death of the English physician and chemist, William Prout, Munk recorded in his Roll of the Royal College of Physicians: ' 'I am not aware that any full and searching estimate of Dr. Prout's merits as a philosopher and chemist has yet appeared.' Munk's remark remains true today, for no definitive life of Prout has ever been written, ${ }^{3}$ and indeed, Munk's own sympathetic account is still the most readily available biographical source. ${ }^{4}$ Such neglect is surprising, for Prout's name is a familiar one in textbooks of chemistry and physics associated with the unitary hypothesis that the chemical elements possess atomic weights which are integral multiples of the atomic weight of hydrogen. ${ }^{5} \mathrm{He}$ is otherwise featured in a minor way in histories of chemistry and medicine as the discoverer of hydrochloric acid in gastric juice, and as an early organic analyst. 6 The purpose of the present essay is to attempt to provide a satisfactory account of Prout's intellectual life based upon contemporary sources, his own writings, and some information kindly given by his descendants.

1 Med. Times, $1850,1,17$.

3 vols., 1878 ; cf. vol. III, p. 110.

8 But see Kasich, A. H., Discovery of hydrochloric acid in gastric juice, Bull. Hist. Med., 1946, 20 340-58. There are a few surviving letters (6 in the Royal Society, 2 in the Royal College of Physicians). Some of Prout's chemical notes have been recovered recently, and through the kindness of Lt.-Col. P. E. H. Warner they have been passed to me for examination. Fortunately-or unfortunately-they do not impel me to make any significant alterations to the present paper, although they considerably expand our knowledge of Prout's ideas on the nature of matter. A list of these papers, together with a few remarks, is now given. ( $\mathrm{I}$ ) 'Sketch of the History of Physic', 97 pp., dated Edinburgh, July I809 and described as 'Read August 10, 1809'. An account of medical systems from Hippocrates until the end of the sixteenth century. The audience is not known. (2) 'Dissertatio de Sonis et Actione harmonia Auris humana', Edinburgh, 181o, 39 pp. An undergraduate essay. (3) 'De Facultate Sentiendi', Edinburgh, 1810, 26 pp., in English. This undergraduate essay sheds fresh light on the origins of Prout's Hypothesis. A full text will be published elsewhere. (4) Waste book consisting of abstracts of Prout's reading in animal and vegetable chemistry. Date circa 1812 to 1814 . (5) Notes and drafts for the Animal Chemistry Lectures of 1814 . With the exception of the introduction to these lectures, which relates to a theory of matter, there is little original material here. Prout's lectures were of the review type and formed the basis for the 1816 paper on blood. (6) Waste book and notes on the molecular theory of the Bridgewater Treatise. In addition, although fresh biographical information has not been uncovered, there is much documentary evidence concerning Prout's ancestors and children.

'Hartog's notice in the Dictionary of National Biography was drawn largely from Munk, who in turn had drawn heavily upon Daubeny, C., Miscellanies, London, 1867, vol. II, 123-7 (reprinted from Edinb. new Phil. F., 1852, 53, 98-102), and the anon. obituary, Med. Times, 1850, 1, 15-1 7 (cited as Med. Times). There is a good analysis of Prout's life and work in Edinb. med. surg. $\mathcal{7}$., 1851, 76, $126-83$.

'Introduction, Dobbin, L., and Kendall, J., Prout's Hypothesis, Alembic Club Reprint, no. 20, Edinburgh, r 932. See also, Glasstone, S., 7. Chem. Educ., 1947, 24, 478-81; Benfey, O. T., ibid., 1952, 29, 78-81; Siegfried, R., ibid., 1956, 33, 263-6.

- Partington, J. R., A History of Chemistry, London, 1963, vol. III, pp. 713-14. 
The neglect of Prout's work had already set in long before he died in $185^{\circ}$. At least two reasons may be proposed for this. First, Prout's chemical career was essentially finished by 1834 when he published his Bridgewater Treatise; thereafter he devoted himself almost entirely to his medical practice and the revision of his books. Second, as these revisions show only too clearly, Prout was unable to keep abreast of contemporary developments in chemistry and physiology, so that although much of his research had foreshadowed that of Liebig and his school, he found himself and his work eclipsed by their achievements in the 1830 ond 1840 os. The Royal Society and the Chemical Society ignored his death $^{7}$ and it was left to the physicians to pay him tribute in the chief medical journals of the day.

William Prout was born on the 15 January 1785 at Horton, near Chipping Sodbury, in Gloucestershire, where his family had lived on their own property for some generations. His parents were of farming stock - the father, John Prout, died in 1820 'in consequence of having run a thorn into his hand which occasioned a locked jaw' ${ }^{8}$ Like many other nineteenth-century physicians of humble origin, Prout's earlier education was almost negligible. Although he learned to read and write at a local Dame school, and later at Badminton village school, this elementary education had ceased by the age of thirteen. From then until he was seventeen, little is known of him except for the report that during his youth he suffered from an intense earache-no doubt a forerunner of the deafness which later forced him to withdraw from scientific society. At the age of seventeen Prout became critically aware of his own educational deficiencies, and with an awakened interest in mechanical things, mathematics and music, he determined to engage upon some systematic learning. With this aim he left home for some eighteen months between 1802 and 1804 to join a private Academy at Sherston in Wiltshire run by the Rev. John Turner, Vicar of Horton and Luckington in Wiltshire. ${ }^{9}$ Here he acquired the rudiments of Latin and Greek-an essential training for a university course, whether or not he yet had that ambition. However, Prout returned home, either dissatisfied with his own progress, or with the standards of Turner's Academy, since some time in 1805-6 he took the extraordinary step of advertising in a local newspaper for advice on the prospects for further learning for an ill-educated twenty-year-old.10 A reply came from another clergyman, the Rev. Thomas Jones (I 758-1812) who ran a classical seminary at Redland, Bristol. Jones had been educated at Cambridge and Dublin, and had been Vicar of two Devonshire parishes before he opened his 'classical seminary for young gentlemen' at the turn of the century. Prout spent two happy and formative years with Jones. ${ }^{11}$ In return for his tuition, he taught the younger pupils of the Academy, and stimulated by a pupil's curiosity in chemistry (these were the exciting days of early electro-

\footnotetext{
7 Perhaps because Gay-Lussac, who also died in 1850 , required a long eulogy. Prout served on the Council of the Royal Society from 1826 to 1828 .

8 Gents. Mag., September 1820 , p. 284.

- Sherston is only a few miles from Horton. For Turner, see Gents. Mag., 1848, ii, 215.

${ }^{10}$ It would be amusing to trace this advertisement. I could not find it in the Gloucester fournal. A likely source is Felix Farley's Bristol Fournal.

11 For Jones, see Venn, J. A., Alumni Cantabrigiensis, Part II (1752-1800), Cambridge, 1947, vol. III, 608. Prout later christened his youngest son, Thomas Jones.
} 
chemistry), Prout himself began to form what was to become a lifelong passion for the subject. It was Jones who urged Prout to become a doctor and recommended him to enter the University of Edinburgh. (Oxford and Cambridge were naturally out of the question as Prout's social status was so low.) Thus in I808, at the mature age of twenty-three, Prout went to Edinburgh armed with a letter of introduction to Jones's old teaching friend, Dr. Alexander Adam, Rector of the Edinburgh High School. He remained in Edinburgh for the three-year period except for visits to the country villages of Duddingston and Morningside during the summer vacations. These were sufficiently close to the university (we are told) to ensure full use of the library; however, we may suspect that Adam's elder daughter, Agnes, was an additional Scottish attraction. Nothing is known of Prout's days as a medical student, for like the vast majority of undergraduates he left no mark upon his university, or the medical societies of Edinburgh. ${ }^{12}$ His teachers would have been Monro tertius, Duncan and Hope, and among medical students contemporary with him were Marshall Hall, John Davy, Henry Holland, and the man who evidently became one of Prout's closest friends, John Elliotson. ${ }^{13}$ Prout graduated M.D. on 24 June I8 I I, with a thesis on intermittent fevers which contained no original features: $:^{14}$ it is a straightforward academic review of fevers proceeding by way of definitions, symptoms, causes, pathology, prognosis and treatment.

After graduation, Prout left Edinburgh and took rooms off Leicester Square in London where, until he gained the licentiate of the Royal College of Physicians on 22 December 1812, he walked the wards of the United Hospitals of St. Thomas's and Guy's. ${ }^{15}$ In this way he came into contact with the great surgeon, Astley Cooper, and the animal chemist, Alexander Marcet. Armed with his licence, Prout set up a practice at 4 Arundel Street, just off the Strand, and it was here in 1813 that he began his active career as a chemist and physiologist. Thomas Thomson on his return from Sweden in 1812 had begun to publish an important monthly periodical, the Annals of Philosophy, ${ }^{16}$ and it is from early issues of this journal that we learn that in 1814 Prout delivered a course of lectures at his home, 'the attendance on which though small was select, and so highly was he already esteemed, that his audience included Astley Cooper'. ${ }^{17}$ Two published advertisements read:

Dr. Prout intends in the course of the winter, to deliver a series of lectures on Animal Chemistry. The object of these will be to give a connected view of all the principal facts belonging to this department of chemistry, and to apply them, as far as the present state of our knowledge will permit, to the explanation of the phenomena of organic actions. ${ }^{18}$

\footnotetext{
12 I owe confirmation of this to Dr. Douglas Guthrie.

${ }^{18}$ Harley Williams, J. H., Doctors Differ, London, 1946, Part 2. The friendship is not noted in this short biography of Elliotson.

14 De febribus intermittentibus, Edinburgh, $181 \mathrm{I}, 27 \mathrm{pp}$. There is no dedication or indication of membership of student societies. Two copies Edinb. Univ. library.

${ }_{15}$ Munk, op. cit., p. rog. The oral Latin examination for the licentiate consisted of questions in physiology, pathology, therapeutics and the interpretation of a passage from either Celsus or Sydenham.

1628 vols., $1813-26$.

17 Munk, op. cit., p. 109, based his statement on Med. Times, p. 15, which said Prout's course was in 1813. Either there were two annual series, or the 1813 announcement has been confused with the 1814 realization.

${ }_{18}$ Ann. Philos., October 1813, 2, 312.
} 


\section{W. H. Brock}

Dr. Prout will commence a course of lectures on Animal Chemistry on Friday, February 18 [1814], at half-past eight in the evening. These lectures will be given at his residence, 4 Arundel Street, Strand, and will be continued weekly at the same hour. ${ }^{19}$

Lecture courses in private houses were not uncommon at this time, ${ }^{20}$ although accounts of them were rarely published. From hints in Prout's publications, we may conjecture that he lectured on respiration and urine chemistry.

The year 1814 was an extremely busy and eventful one for Prout since, besides his lecture course which would have brought him forward prominently in the circle of London scientists, he was elected a Fellow of the Medico-Ghirurgical Society, he was married, he visited Paris, he continued analysing animal materials, and he performed his offices as a professional physician. His election to the flourishing Medical Society took place on to May, and his association with it continued for many years. He read several papers to its members, served as a member of Council from 1817 to 1819 , and as a Vice-President in 1823 and from 1833 to $1835 .{ }^{21}$ Prout was married on 22 September 1814 at St. John's Church, Westminster, to Agnes Adam (1 793-1863). ${ }^{22}$ Europe was momentarily at peace, so the Prouts were able to pay a honeymoon visit to Paris where, like Humphry Davy before them, they were able to have a private view of the paintings and treasures which Napoleon had collected during his campaigns with the aid of Baron Dominique Denon. On their return to England, the Prouts settled at Southampton Street, Bloomsbury, where a daughter was born to them in 1815. The child only survived a few months, but there were six further children. A son, John William, who became a lawyer, was born in 1817 ; a second son, Alexander Adam, of whom little is known, came in 1818; Walter, born in 1820, lost his life as a major during the Indian Mutiny; a fourth son, Thomas Jones, was born in 1823 and became a clergyman and classics don at Christ Church, Oxford. There were also two daughters, Elizabeth born in 1825, and Agnes in $1826 .{ }^{23}$ The house where the family resided from 1821 to $185^{\circ}$ (4o Sackville Street, Piccadilly) is no longer standing.

\section{Early analytical work}

Apart from the dissertation of 18 I 1 , Prout published nothing until I8I3. However, a review note on progress in physiology for 1820 written by a 'friend' of Thomson for his Annals ${ }^{24}$ (it is possible that the writer was Prout) ${ }^{25}$ discussed

10 Ann. Philos., 1814, 3, I51.

20 There was an 'Animal Chemistry Club' or 'Society for the Promotion of Animal Chemistry' whose membership included Brodie, Home, Davy, Babington, Brande and Clift, but this had 'degenerated into a mere dining club' by 1813 .

${ }_{21}$ cf. Officer lists, Med. chir. Trans., 181 7, 8; 1833, 18; 1835, 19, xli.

${ }^{22}$ Gents. Mag., October 1814 , p. 392. For Adam, see D.N.B. Agnes was his eldest daughter by a second marriage.

${ }^{23}$ I have to thank Lt.-Colonel P. E. H. Warner, M.B.E., M.C., Prout's great-great-grandson, for these details.

24 Ann. Philos., 1820, 16, 113.

25 A passage in the review on the nervous system also hints at Prout's authorship. 'It would be well for physiology if its cultivators would leave for a while this abstruse and difficult subject and turn their attention to something more within their power; [like the] chemical and mechanical constitution of organic bodies; for till this is known, it is evident we can hope for very little progress in physiology.' Ibid., p. I13. A similar plea was made by Prout in his Gulstonian lectures. However, Prout's paper on blood (1819) was not mentioned in the review. Would he have ignored this and yet have resurrected an idea from 1811 ? 
Blainville's theory that teeth were analogous to hair and nails, and mentioned that:

A similar opinion was advanced in 18 I I by Dr. Prout, who at that time drew up the sketch of a paper, the object of which was to prove that the teeth are to be considered as appendiges to the integuments, and to be classed with horns, nails, \&c. The opinion was principally founded upon extensive anatomical inquiries, showing the analogy between the formation of the teeth, horns, feathers, \&c., and partly also upon physiological and pathological reasonings. The paper was never published, owing to reasons which need not be mentioned, but the opinion was stated to many of the author's friends at the time, and he intends at some future opportunity to lay the subject before the public in extended form.

Needless to say, no paper on this subject was ever published by Prout, and his first paper written in June 18 I 3 was of a histochemical character. It would seem, therefore, that his earliest interests were anatomical. The problem which Prout had examined was how to stain the blood vessels of anatomical specimens by the old art of anatomical injection. ${ }^{26}$ After several trials he had found that a saturated solution of potassium ferrocyanide and dilute ferric sulphate would successfully plant prussian blue in the morbid tissues. The injections were made through a syringe pipe after the solutions had been heated to $100^{\circ} \mathrm{F}$., but the order in which the solutions were injected was immaterial. In an investigation of the vascular nature of the ox's eye, Prout found that 'the vessels of all parts of this organ appear to communicate freely with one another; the part least connected with the rest is the retina, and this is supplied by its own proper artery'. He successfully stained the lens capsule and decided that the hyaloid membrane in the adult state at least ... derives all its vessels from the great arterial communication situated a little behind the ciliary ligament, and not from the retina, as usually stated'.

In the same year (1813) Prout published his first paper in Thomson's Annals, 'Observations on the Quantity of Carbonic Acid Gas Emitted from the Lungs during Respiration, at different Times, and under different Circumstances'. ${ }^{27}$ His intention was to determine both whether the quantity of carbon dioxide exhaled in the breath was constant throughout the day, and constant for the individual. The analyses were made on himself with the aid of a breathing apparatus similar to the modern spirometer. ${ }^{28} \mathrm{~A}$ strict regimen was necessary 'which consisted in keeping myself as nearly as possible in the same state in every respect'. He stuck to this 'arduous' discipline for nearly three weeks during August 1813, 'making experiments every hour, and sometimes oftener, during the day, and occasionally during the night also'. ${ }^{29}$ Prout thought he perceived a pattern in his results, and he stated as a law:

The quantity of oxygen consumed, and consequently of carbonic acid formed during respiration, is not uniformly the same during the 24 hours, but it is always greater at one and the same part of the day than at any other, that is to say, its maximum occurs between 10 a.m. and 2.0 p.m., or generally between II.0 a.m. and I.0 p.m.; and its minimum commences about 8.30 p.m., and continues nearly uniform till about 3.30 a.m. ${ }^{80}$

${ }_{26}$ London med. phys. F., 1813, 30, 89-96; cf. Cole, F. J., History of Anatomical Injection, in Singer, C. (ed.), Studies in History and Method of Science, 1921 , vol. II, pp. 285-343.

${ }_{27}$ Ann. Philos., November 1813, 2, 328-43.

$28 \mathrm{He}$ made it clear that he was measuring potential carbon dioxide formation.

20 Op. cit., p. 328 . He appears to have worked at night on twelve occasions in three weeks.

${ }^{30}$ Ibid., p. 329. 


\section{W. H. Brock}

Prout was of course misled by his regimen and ignorance of cellular chemistry; however, all of his results are explicable in terms of the influence of $\mathrm{pHCO}_{2}$ on the oxygen dissociation of haemoglobin, and nervous stimuli. In a second generalization Prout foreshadowed the findings of Haldane and Priestley:

Whenever the quantity of oxygen gas consumed, and consequently of carbonic acid gas formed, has been by any cause increased, or raised above the standard of the period, it is subsequently as much decreased or depressed below that standard, and vice versa. ${ }^{31}$

His experimental work included investigating the effects of exercise, eating and drinking (alcohol and tea), and the 'depressing passions' (i.e. emotional states conducive to yawning, sighing, or deep inspirations). Prout speculated that a diurnal cycle-the presence or absence of the sun-might bring about these observed variations, and he returned to this hypothesis the following year in a further paper ${ }^{32}$ with an elaborate graphical plate which showed how the increase in carbon dioxide exhaled 'always uniformly occurred soon after the commencement of twilight, and before sunrise' ${ }^{33}$ throughout the year. The increase was greatest when the nights were longest, and there was a uniform lessening as the nights decreased in length, 'a circumstance which, however, appears to have been chiefly owing to a diminution having taken place in the usual minimum quantity towards the morning, either probably from the fatigue of watching or from drowsiness'. ${ }^{33}$ This remarkable erroneous observation seems to have been ignored by all of Prout's contemporaries who were little interested in such physiological experiments.

Much more attention was paid to Prout's anonymous papers of 1815 and 1816 which dealt with the calculation of the specific gravities (i.e. relative densities) of the elements from the published data of other chemists. ${ }^{34}$ Among many results, he was able to give an excellent value for hydrogen which, owing to its lightness, had been extremely difficult to determine experimentally with any accuracy. Although when read today it is possible to see that the more important theme of Prout's papers was Avogadro's hypothesis that equal volumes of gases under identical physical conditions contain the same numbers of molecules, the papers were written in such a confused 'hasty and imperfect manner' that this molecular hypothesis became overshadowed for the contemporary reader by the protyle hypothesis. Thus it was not clear from these papers alone what Prout understood by volume, atom, and molecule; but it was clear from his results that there was a remarkable connection between the atomic weights of the elements on the hydrogen scale. The suggestion that the chemical elements were condensed from hydrogen atoms became known as 'Prout's hypothesis' and it attracted the attention of analysts and theorists throughout the nineteenth century. ${ }^{5}$ Although these papers were written anonymously, Prout quickly identified himself as the author when he found his ideas had been accepted by so eminent a chemist as Thomas Thomson. ${ }^{35}$ Prout was content to

81 Op. cit., p. 340

83 Ibid., p. 333 .

${ }^{32}$ Ann. Philos., November $1814,4,331-7$.

${ }^{84}$ Ann. Philos. $1815,6,321-30 ; 1816,7$, 1 I $1-13$.

s5 Prout submitted his papers with the greatest diffidence under the cloak of anonymity, yet subsequently went out of his way to acknowledge his authorship on many occasions. Thomson's revelation is well known, Ann. Philos., May 1816, 7,343, but this was followed immediately by Prout himself, Ann. Med. Surg., June 1816, r, 150. 


\section{The Life and Work of William Prout}

leave the promotion of his speculation to the status of a law to Thomson while he himself returned to organic analysis ${ }^{36}$ where, during the decade $1815^{-25}$, he attained a considerable reputation both in Great Britain and on the Continent.

Prout continually searched for a perfect technique of organic analysis. A good example of his qualitative method is his analysis of a snake's excreta in $1815{ }^{.37}$ The faeces of a boa constrictor, then currently on exhibition in the Strand, was dissolved in hydrochloric acid and the insoluble portion shown to be uric acid by the murexide test. The soluble portion was found to consist of lime (by an ammonium oxalate test) and ammonium chloride. Prout was obviously surprised that the excrement was almost pure uric acid (90.16\%), for he wondered whether the serpent had become diseased through captivity, though he recalled that Wollaston had previously demonstrated that the bird-droppings from South America called guano also comprised uric acid. Confirmation of Prout's analysis soon came independently from his friend John Davy in Ceylon, and from Davy's cousin, Edmund Davy in $1819 .{ }^{38}$

In the gravimetric analysis of organic substances, Prout demonstrated how Wollaston's equivalent slide-rule, or Synoptic Scale of Equivalents, could be used to work out - what we would now call - the empirical formula of a substance assuming, as Berzelius had maintained, that organic substances obeyed the law of definite proportions. ${ }^{39}$ At this time, $c$. I ${ }_{15}$, Prout's method of analysis was still the technique introduced by Gay-Lussac and Thenard of oxidation by potassium chlorate in an apparatus somewhat similar to [that used by] Berzelius'. Prout stressed the necessity for drying materials to be analysed and suggested the use of sulphuric acid for this purpose in a vacuum apparatus of his own design. When Gay-Lussac introduced the use of copper oxide in 1816 , Prout rapidly developed a spirit-lamp apparatus which was 'susceptible of far greater precision, and is much less troublesome to use than any that has hitherto been recommended for the analysis of organized substances'. ${ }^{40}$ As a comment on this, Daubeny later wrote:

The greater part of Dr. Prout's analyses were made with an apparatus of his own which, however ingenious it might be, was far more difficult to use, and required for its success many more precautions than that at present in the hands of chemists, and hence the precision to which he attained is the greater subject for commendation. Add to which, that these delicate investigations were carried on by him, unassisted, amid constant interruptions, at intervals snatched from the daily demands made upon his time by professional engagements. ${ }^{41}$

\footnotetext{
${ }^{36}$ ' $I$ soon found my progress obstructed by insuperable difficulties. The first and chief of these was the want of accurate data; and the infinity of objects comprehended by chemistry prevented the hope of acquiring by individual exertion, however unremitting, a sufficiency for the establishment of general laws. Professional duties still further limited my exertions, and at length obliged me to relinquish chemistry in general, and confine my attention solely to the chemistry of organic substances.' Phil. Trans., 1827 , p. 354 .

${ }^{37}$ Ann. Philos., 1815, 5, 413-16.

88 Davy, J., Phil. Trans., 1818 , p. 303, dated Ceylon, 25 March I81 7, Davy says Prout informed him of the analysis before he left England; Davy, E., Phil. Mag., I819, 54, 303-6.

${ }^{39}$ Ann. Philos., 1816, 6, 269-73. Wollaston's slide-rule, which was sold by instrument-makers, had been described to the Royal Society in 1813, Phil. Trans., 1814, pp. 1-22. At this time, of course, empirical and molecular formulae were thoroughly confused.

4 Ann. Philos., 1820, 15, 190-2.

11 Edinb. new Phil. J., 1852, 53, 99.
} 


\section{W. H. Brock}

Eventually, in his constant quest for accuracy, Prout returned to Lavoisier's method of analysis by direct oxygen combustion. But long before this development he was able to claim:

I have for several years been engaged in the analysis of organized products, and have at length extended my researches to almost every distinct and well-defined substance. The results, when compared with one another, are most interesting, and seem to throw no small light not only on the nature of chemical compounds in general, but upon many important points connected with animal and vegetable physiology and pathology. ${ }^{42}$

This statement brings us to his work on urine and digestion.

Prout's interest in the chemistry and pathology of the urine dated from the lecture period of 1814 , and his researches on the analysis and chemotherapy of diseased urine were fully expounded in a paper which he read before the Medico-Chirurgical Society on 24 June $1817.43 \mathrm{He}$ had been the first person to obtain a really pure sample of urea from urine in 1814 , and his method, which involved the use of animal charcoal, became the standard technique in chemical textbooks. ${ }^{44}$ After he had carefully described the chief chemical and physical properties of urea, Prout reported on its analysis. The atomic weight values he used were those of the anonymous paper of 1815 , and the proportional number (i.e. empirical formula weight) of 37.5 which he calculated was employed by Wöhler in his famous paper on the synthesis of urea ten years later. ${ }^{45}$ Prout also gave analyses of urea nitrate, sugar, sugar of milk, and diabetic sugar, but he found so little difference between the sugars that he concluded ' $I$ am inclined to think the primary and simple saccharine principle is composed of one atom of each element, and that the varieties in its external characters are to be attributed to the influence of the presence of minute portions of foreign matters, analogous, for example, to what occurs in the mineral called arragonite.' 46 Ten years later he elaborated this speculation into the cumbrously titled concept of 'merorganization'. The chemical portion of the paper was concluded with three generalizations: ${ }^{47}$

I. The atomic theory or theory of definite proportions, holds good in all these instances.

2. The above compounds appear to be formed by the union of more simple compounds, as urea of carburetted hydrogen and nitrous oxide, lithic acid of cyanogen and water, \&c.; circumstances which render almost certain that their artificial formation falls within the limits of common chemistry. ${ }^{48}$

3. The remarkable relation found to subsist between urea and sugar, seems to explain in a very satisfactory manner the phenomena of diabetes, which may in fact be considered to consist in a depraved secretion of urea. Thus the weight of the atom of sugar (18.75) is just half that of urea (37.5); the absolute quantity of hydrogen in a given weight of both is equal, while the absolute quantities of carbon and oxygen in a given weight of sugar are precisely twice those in urea.

42 Ann. Philos., 1820, 15, 192.

18 Med. chir. Trans., $1817,8,526-49$. There is a bound offprint in Edinb. Univ. library which bears the dedication, 'Dr. Duncan, Sen. with the authors best respects.' Andrew Duncan (1 744-1828), Prof. of Physiology, was one of Prout's teachers at Edinburgh.

41 e.g. Turner, E., Elements of Chemistry, London, $1833,4^{\text {th }}$ ed., p. 871 .

${ }^{4}$ Pogg. Ann. der Physik, 1828, 12, 88.

16 Med. chir. Trans., $1817,8,538$.

17 Ibid., pp. 540-1.

$18 \mathrm{My}$ italics. This generalization is an early example of the radical theory. Prout evidently made several attempts to synthesize urea as he ruefully informed readers of his later clinical text, On Stomach and Renal Diseases, $5^{\text {th }}$ ed., 1848, p. 530. All references will be to this ed., cited as On Stomach. 


\section{The Life and Work of William Prout}

Such analyses afforded Prout 'glimpses of laws that will hereafter be found to influence the whole system of Nature's operations'. The Pythagoreanism, or fixation with numbers, first noticed in the anonymous paper of 1815 , which reappears in the last paragraph of this quotation, was returned to in a further paper on the chemical constituents of urine in $1818 .{ }^{49}$ Since the previous paper Prout had found many imperfections in his analytical methods, and after a tabulation of corrected results he drew the reader's attention to 'the extraordinary relations that exist among the ... numbers'. ${ }^{50}$ The molecular weights of sugar, urea, uric acid, cystine (the presence of sulphur was overlooked) and oxalic acid, seemed to form a simple arithmetical series. From here it could have been but a small step to the metamorphosis theme of the Bridgewater Treatise where molecules underwent reduction or completion to the designs of organic agents. ${ }^{51}$

$\begin{array}{lcccccc}\text { Ioo parts contain } & \text { H } & \text { G } & \text { O } & \text { N } & \text { mol. wt. } & \text { sugar=I } \\ \text { sugar } & 6.66 & 40 \cdot 00 & 53.33 & - & \text { 18.75 } & \text { I } \\ \text { urea } & 6.66 & 20 \cdot 00 & 26.66 & 46.66 & 37.50 & 2 \\ \text { uric acid } & 2 \cdot 22 & 40 \cdot 00 & 26.66 & 31 \cdot 11 & 56 \cdot 25 & 3 \\ \text { cystic oxide } & 5.00 & 30 \cdot 00 & 53.33 & 11.66 & 75 \cdot 00 & 4 \\ \text { oxalic acid } & 4.44 & 20 \cdot 00 & 75.55 & - & \text { I12.5 } & 6\end{array}$

A second part of the 1817 paper was addressed to the medical practitioner. Although empirical in theme and content, Prout firmly stated his belief that 'reason will become triumphant eventually, so that chemotherapy will be placed upon a deductive basis'.52 Unlike many physicians, Prout had no wonderful remedy to offer for the stone; the only real solution was the knife, for 'when a calculus is once formed, a further enlargement is probably a common chemical process, and will proceed whether the urine be healthy or not, for all the urine naturally contains the ingredients most commonly met with in calculi'. ${ }^{53} \mathrm{He}$ was very sceptical of so-called chemical remedies both because of their potentially dangerous side-effects, and because 'the object of the chemical practitioner is ... to prevent the effects of diseases rather than to remove them ${ }^{34} \mathrm{He}$ mentioned that he had practised uromancy for several years before he had met Charles Scudamore, 'who I found entertained similar views, and had prosecuted the subject much further than I had done'. ${ }^{55}$

Prout's work with urine for which he devised a special hydrometer ${ }^{56}$ led him to the discovery of a substance Wollaston and he named purpuric acid. This research formed the subject of Prout's first communication to the Royal Society to whom it was read by Wollaston, and it led directly to his election to a

10 Med. chir. Trans., 1818, 9, 472-84.

50 Ibid., pp. $483-4$.

51 See my forthcoming 'Prout's molecular theory', B.J.H.S.

${ }_{52}$ Med. chir. Trans., 181 7, 8, 543.

53 Ibid., p. 546 .

54 Ibid., p. 549. Several chemical remedies had been mentioned by Marcet, A., Chemical History and Medical Treatment of Calculus Disorders, London, 1817 , 2nd ed., 1819 .

55 Ibid., pp. 543-4. Sir Charles Scudamore (1779-1849) was the author of Treatise on Gout and Rheumatism, $18 \mathrm{I} 6$. He had given Prout samples of urine and freely discussed the subject with him, cf. op. cit., and ed., 1817 , p. 297.

${ }^{6}$ Ann. Philos., 1825, 25, 334-5. Prout says that his 'urinometer' was in general use among practitioners, On Stomach, p. 180 n. 


\section{W. H. Brock}

Fellowship in March 1819. The proposal was made in the hand of Alexander Marcet and was countersigned by Wollaston, Warburton, Koenig, Roget, Leigh Thomas, Blane and Baillie. ${ }^{57}$ The purple colour produced by the action of dilute nitric acid on uric acid had been first described by Scheele, the discoverer of lithic or uric acid. Prout now explained the origin of the colour as due to an ammonium salt of an acid - to be called purpuric 'from its remarkable property of forming compounds with most bases of a red or purple colour'. ${ }^{58}$ After accurately describing its preparation, he explained how the acid could be freed from the ammonia of the dark red crystalline salt by the addition of a mineral acid. However, as Prout later realized, it was not actually the free acid that was prepared in this way, but the substance Liebig called murexid. ${ }^{59}$ The remainder of his paper was devoted to a description of a variety of inorganic purpurates. He wrongly believed that ammonium purpurate was responsible for the pink sediment 'in urine of those labouring under febrile affections', ${ }^{60}$ and he speculated that purpuric acid and its compounds were the basis of many animal and vegetable colours, and hence that it might prove of industrial and artistic use. ${ }^{61}$

Another new acid was announced in 1822 when Alexander Marcet read a paper to the Medico-Chirurgical Society on 'a singular variety of urine which turned black soon after being discharged'.62 Marcet had obtained the sample from Babington way back in $18 \mathrm{r} 4$; the patient had been a male child of seventeen months who was evidently suffering from alkaptonuria. Marcet had retained the sample and only recently sent it to Prout for analysis. The latter reported that the black colour was due to an unknown principle combined with ammonia which he appropriately dubbed melanic acid. As Partington has pointed out, this was homogentisic acid. ${ }^{63}$ The fact that Marcet, who was more than capable of making such an analysis himself, sent the sample to Prout, illustrates the position which Prout had attained as an expert in urine analysis. As for the reasons for his researches, Prout stated in the same year:

The views which I published some years ago respecting the atomic theory, seem to be now generally known in this country. ${ }^{84}$ These views at the time led me to others which I was exceedingly anxious to verify; and as I was interested, for other reasons, in the composition of organic substances, it struck me that by submitting these substances to analysis, I might not only obtain a knowledge of their composition, but by investigating the laws which might regulate the union of the elements, hydrogen, carbon, oxygen, and azote, be able to obtain an insight into the laws which regulate the union of other elementary principles. With these views, therefore, I set to work, and after a very great labour, and no trifling expense in apparatus, \&c., succeeded, as I supposed, in analyzing more or less perfectly almost every well-defined and crystallized organic substance that I could procure. A few of my earlier results

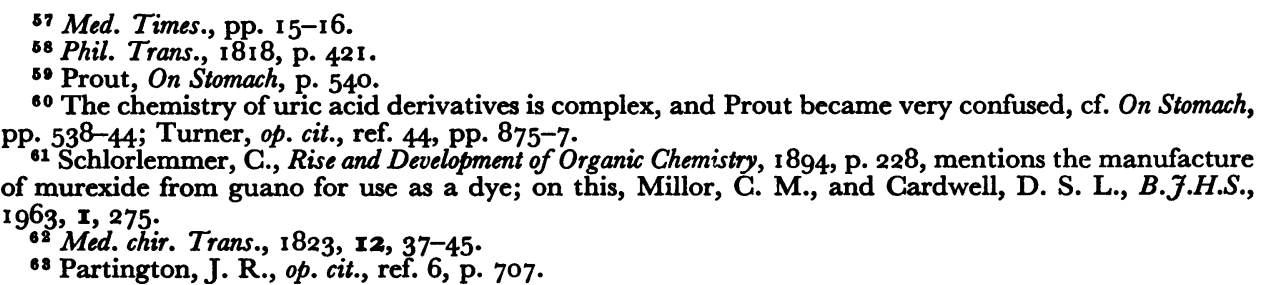




\section{The Life and Work of William Prout}

were published, perhaps prematurely, but the great mass, as is well known to several of my friends, still remain by me, nor have I for various reasons, the least inclination to publish them at present. ${ }^{84}$

Unfortunately, it would seem that little of this analytical mass was subsequently published. We may suspect that Prout was a perfectionist and that he was unprepared to publish authoritative analyses until he was certain that his technique was accurate and not open to improvement.

The whole of Prout's work on urine was elaborated into a book which 'established his reputation as a chemist and practical physician' ${ }^{65}$ In a preface to the Inquiry into the Nature and Treatment of Gravel, Calculus and Other Diseases of the Urinary Organs (1821), 66 Prout mentioned 'his original intention to prefix an historical introduction respecting the urine, with a detailed account of the chemical experiments on which many of his peculiar views are founded; but upon reflection he was induced to relinquish both these objects for the present, and to confine his attention chiefly to practical points'. Indeed, the practical tone of the book remained paramount in all five editions-a misfortune to us, and a source of justifiable irritation to his reviewers.

\section{Work on Digestion}

There was a short-lived medical journal called The Annals of Medicine and Surgery; or Records of the Occurring Improvements and Discoveries in Medicine and Surgery and the immediately connected Arts and Sciences, which appeared quarterly during 1816-17. The editors are not definitely known, although there is a suggestion by one of Prout's obituarists that they were Prout and his friend John Elliotson. ${ }^{67}$ Unfortunately, none of Prout's published writings makes any allusion to the editorship, and it has not proved possible to demonstrate the association of Prout and Elliotson with the journal from internal evidence. However, it is not impossible, for Prout and Elliotson were good friends; Elliotson frequently gave pathological samples to Prout for analysis, ${ }^{68}$ and Prout's suggested iodine treatment of goitre was successfully performed by Elliotson at St. Thomas's Hospital. ${ }^{69}$ But the evidence is conflicting and the matter is by no means settled.

It was in this journal, however, that Prout published the first three parts of

64 Ann. Philos., 1822, 20, 424-5.

65 Munk, op. cit., p. 109 .

66 London, 1821, 277 pp. A hand-painted endpiece was designed to illustrate the various colours assumed by sedimented urine. A 2nd ed. which appeared in 1825 , retitled Inquiry ... Nature of Diabetes, Calculus, and other Diseases, etc., 328 pp., with index, contained a handsome pull-out sheet of calculi illustrations. These engravings by Lunn were also published separately as $A$ Synoptical View of Urinary Calculi, $12 \times 9$ in. (copy R.C.P.). There were French and German trans. of ist ed., and an American printing of 2 nd ed. in 1826 .

${ }^{67}$ Edinb. med. surg. $7 ., 1851,76,144 \mathrm{n}$. 'It has been said that this journal was conducted by Dr. Elliotson and Dr. Prout; but the correctness of this statement we have no means of ascertaining. . . . See my query concerning the editorship, Med. Hist., I964, 8, $291-3$.

${ }_{68}$ e.g. Med. chir. Trans., 1818, 9, 474 (blood sample); ibid., 1819, ro, 390 (calculus); ibid., 1833, 18, 82.

'P Prout, W., Chemistry, Meteorology and Function of Digestion, London, 1834, p. I 00 . All refs. to this ed. cited as Chemistry. He had used potassium iodate as a remedy for goitre in 1816 'after having previously ascertained by experiments on himself that it was not poisonous in small doses. . . . The above employment of the compounds of iodine in medicine was at that time made no secret; and so early in 1819, the remedy was adopted in St. Thomas's Hospital by Dr. Elliotson, at the author's suggestion." 


\section{W. H. Brock}

an 'Inquiry into the Origin and Properties of the Blood'. Later he evidently felt that the Annals had been too limited in circulation, for he had the paper republished in a slightly modified-but again incomplete-form in Thomson's Annals of Philosophy 70 in 1819. The missing part which entailed a long chemical investigation of the chicken's egg was finally presented independently to the Royal Society in 1822 . As the three papers on sanguification show clearly, Prout was involved in the problems of digestion as far back as 1816 when he announced that

the blood begins to be formed, or developed from the food, in all its parts from the first moment of its entrance into the duodenum, or even, perhaps, from the first moment of digestion, and that it gradually becomes more and more perfect as it passes through the different stages to which it is subjected, till its formation be completed in the sanguiferous tubes, when it represents an aqueous solution of the principal textures and other parts of the animal body to which it belongs. ${ }^{71}$

At this time, he divided the process of blood formation into four stages: ( $\mathrm{I}$ ) digestion (confined to the stomach), (2) chymification (confined to the duodenum), (3) chylification (confined to the lacteals), (4) sanguification proper (confined to the blood vessels). Thus we can see how Prout was led to a complete study of digestion as part of a larger programme of physiological research.

In the review of digestion he described an examination of the contents of a rabbit's stomach some two hours after feeding; the food mass was acidic and analysis showed 'traces of alkaline muriate (chloride), with slight traces of an alkaline phosphate and sulphate; also of various earthy salts, as the sulphate, phosphate and carbonate of lime'. ${ }^{22}$ A similar acidity-a well-authenticated observation in contemporary literature-was found in the stomachs of a pigeon, trench and mackerel. As the heterogeneous nature of the fluids in an active animal stomach had caused much confusion, he proposed to divide the contents into saliva, the mucous coat and exhalents of the stomach, and the gastric juice proper whose identity was 'unknown, it never having been obtained in a separate state'. ${ }^{73}$ 'It is evidently some volatile acid, from its effects on litmus paper . . . I considered it in the pigeon as carbonic. There appears, however, to be occasionally another acid which is of much more permanent nature, and it is probably the phosphoric acid. ... .74 Thus, at this period, 1816-19, Prout was far from identifying the gastric acid with hydrochloric acid.

Prout had analysed the chymes of several animals, including dogs and rabbits, in order 'to ascertain if the chyme exhibited any traces of the albuminous contents of the blood', since the stomach contents had not. From comparative analyses of the 'chymous' contents of the duodenum, caecum, colon and rectum, he detected the presence of an 'incipient albumen' and concluded that such

\footnotetext{
${ }_{70}$ Annals Medicine and Surgery, 1816, 1, 10-26, 133-57, 277-89 (cited as Ann. Med. Surg. with page ref.). Ann. Philos., 1819, 13, 12-25, 265-79. There were French and German trans. of the 1819 version. The missing part, 'Experiments on the evolution, \&c., of the blood in the chick in ovo' (Ann. Med. Surg., p. 277), was later published as 'Experiments on the changes which take place in the fixed principles of the egg during incubation', Phil. Trans., 1822, pp. 377-400.

71 Ann. Med. Surg., p. 20; Ann. Philos., I819, r3, 12.

${ }^{72}$ Ann. Philos., 1819, 13, 13 ; not in 1816 version.

${ }^{73}$ Ann. Med. Surg., p. 141; Ann. Philos., 1819, 13, 271.

74 Ann. Med. Surg., p. 143; Ann. Philos., 1819, 13, 272.
} 


\section{The Life and Work of William Prout}

changes as occurred in the alimentary tract were of a purely chemical nature and therefore probably reproducible under laboratory conditions. He suggested that similar comparative analyses should be made of the chyle from various parts of the lacteal system. It did not seem possible to separate the fourth stage of actual sanguification from another physiological process: respiration. However, animal chemists remained quite ignorant of the actual respiratory process and purpose. Prout believed that one function of respiration was to convert chyle into blood by the removal of unwanted carbon, but was 'the carbonic acid given off as carbonic acid by the blood? and an equal volume of oxygen gas absorbed; or was the carbon only given off, which, by combining with the oxygen of the atmosphere, forms the carbonic acid?' It was clear that both animal heat and the assimilation of food were in some way connected with respiration, but Prout thought that 'from the vital character of the processes, we shall probably ever remain ignorant of their precise nature'. ${ }^{75}$ It always remained a failing of Prout's scientific method to see ignorance as a perpetual mystery and an argument for vitalism.

This paper of 1816 , and its reprint in 1819 , raised far more questions than it answered, and today it would be classed as a review. Prout had originally planned a book on digestion, and even composed much of it, for imminent publication was twice announced in the forthcoming books list of Thomson's Annals. It was to be called Observations on the Functions of the Digestive Organs, especially those of the Stomach and Liver; with practical Remarks on the Treatment of some of the Diseases to which these Organs are liable. A description stated that the work would

comprise the results of some of the more important chemical changes which take place during the digestion and assimilation of the food. The practical remarks will principally relate to the proper adjustment and use of remedies, and to the pernicious effects liable to be produced in delicate habits by the constant operations of various slowly acting causes, especially impure or hard waters: illustrated by analyses of the principal waters in common use in the metropolis and its vicinity. ${ }^{78}$

Prout never published any water analyses. Despite two advertisements in February and November I823, the book was never published, though more than likely some of its intended contents found their way into the 1840 edition of Prout's enlarged treatise on urinary diseases. The explanation given later by Prout was that his discovery of hydrochloric acid in the gastric juice in the autumn of 1823 so thoroughly disorganized his assembled material and ideas on the nature of assimilation that he had to abandon the book. ${ }^{77}$ The unknown writer of the Edinburgh Medical and Surgical Fournal's obituary notice of Prout gave three different reasons: ${ }^{78}$ (I) A new edition of Prout's popular text on urine had been called for after the stock of the 1821 edition had become exhausted; (2) Prout's medical practice had considerably increased because of that book's publication, and patients suffering from the stone flocked to his

\footnotetext{
${ }^{35}$ Ann. Med. Surg., p. 156; Ann. Philos., 1819, 13, 279.

${ }^{76}$ Ann. Philos., February 1823, 21, 157 ; November 1823, 22, 398.

${ }^{77}$ Phil. Mag., 1828 (2), 4, 121.

${ }^{78}$ Edinb. med. surg. $\mathcal{7}$., $1851,76,160$.
} 
Sackville Street consulting rooms; (3) Such private time as he had was occupied by the analysis of wines for his Edinburgh friend, Dr. Alexander Henderson. ${ }^{79}$ The latter's well-known classic, History of Wines, Ancient and Modern appeared in 1824, and Prout's analyses of some eighteen wines were presented in an appendix.

These three reasons, coupled with the discovery of hydrochloric acid in gastric juice, would undoubtedly have led to the postponement or abandonment of the book on digestion.

Prout's great discovery of hydrochloric acid in the gastric juice of animals was announced to the Royal Society on I I December I823. ${ }^{80}$ Now recognized as a 'classic of scientific reasoning', the published account in the Philosophical Transactions of 1824 was extremely terse so that whereas most physiologists agreed with Prout's identification, there were chemists prepared to argue the validity of his analytical deductions. Challenges came from Leuret and Lassaigne in France, who claimed to have found free lactic acid in the stomach, and from Tiedemann and Gmelin in Germany, who had found free acetic, butyric and hydrochloric acids. Both parties were engaged on the problems of digestion at the same time as Prout, ${ }^{81}$ and the resulting controversy-which historians of medicine have overlooked-allowed Prout to describe his discovery in more detail:

I detected the free muriatic acid in a fluid ejected from the human stomach so long ago as 1820 , but then thought that its presence was accidental, or that by some means or other, I had deceived myself; and when I actually commenced the experiments in question, I was actually prejudiced in favour of a destructible acid, viz., the lactic acid of Berzelius (though the distinct nature of this acid always, I confess, appeared to me somewhat problematical). ${ }^{82}$ In consequence of this prejudice therefore, the inquiry was conducted in a much more rigorous and elaborate manner than it probably otherwise would have been; and after a series of the most complete evidence that perhaps was ever brought to bear on a chemical point, I was obliged to conclude, is [sic, in] opposition to my preconceived notion, that the acid was the muriatic acid and no other. On reflecting, however, on this most unexpected fact, I soon saw its importance, and that in short, it was one of those leading facts that opens up an entire new field of inquiry. So satisfied indeed was I of this, that a work on the digestive functions, in which $I$ had long been engaged, and which I had actually begun to print, was suppressed; and since that time I have been engaged in an entire new field of research which I fear will yet occupy me for several years to come. ${ }^{83}$

He then proceeded to justify the conciseness of the announcement of his discovery to the world. Prout had been completely satisfied that

the acid present was the muriatic and no other, at least in any appreciable quantity. Now it was in the knowledge thus previously acquired, and not at random, that the method proposed

79 Munk, op. cit., vol. III, p. 69.

${ }^{80}$ Phil. Trans., 1824, pp. 45-9; reviewed by Kasich, op. cit., ref. 3. The date of the discovery, 1823, has been misprinted 1803 in many secondary sources; others suggest 1834 and 1840 - the latter source attributes the discovery to 'Sir William Prout'.

${ }_{81}$ Leuret, F., and Lassaigne, J., Recherches Physiologiques et Chimiques pour Servir a l' Histoire de la Digestion, Paris, 1825; Tiedemann, F., and Gmelin, L., Recherches Experimentales Physiologiques et Chimiques sur la Digestion, Paris, 1826, also in German, Die Verdauung nach Versuchen, 2 vols., Heidelberg, 1826; Prout, W. (on work of four former), Ann. Philos., 1826, 28, 405-10; Tiedemann and Gmelin (reply to Prout), Phil. Mag., 1828 (2), 4, 3-5; Prout (final reply), Phil. Mag., 1828 (2), 4, 120-3.

82 i.e. presence of lactic acid should have been obvious if it really were present. Notice that Prout does not mention that in 1816 he had favoured phosphoric acid.

${ }^{88}$ Phil. Mag., 1828 (2), 4, 120-1. 


\section{The Life and Work of William Prout}

was founded. . . ${ }^{84}$ If it be objected that these preliminary experiments ought to have been given, I can only say that I did not at the time think this necessary, nor do I now. The muriatic acid was not a new substance, nor one difficult to be identified: besides, such a preliminary inquiry seemed to be sufficiently indicated by the method proposed; for who would ever think of proposing a formal method of analysis, involving the quantities of substances, without determining beforehand what those substances were? Further, my paper was intended to be little more than a simple announcement of an important fact which, before it could be established, I well knew must be corroborated by other experiences than mine; and lastly, something must be ascribed to a sort of innate antipathy to long-winded dissertation which is too apt to cause me to err on the side of brevity. ${ }^{83}$

The discovery of free hydrochloric acid in the stomach was confirmed by Tiedemann and Gmelin in February 1824 , and by J. G. Children, Secretary of the Royal Society, also in 1824 from the observation of a dyspepsic and sceptical friend. ${ }^{85}$ None the less, there were many sceptics; the most bitter opponent was Richard Thomson, Lecturer in Practical Chemistry at Glasgow, and nephew of Thomas Thomson. Like Prout, Thomson seems to have been unaware of Beaumont's findings, and he attacked Prout before the British Association in $1839^{86}$ and in several articles. Prout made a dignified reply in his clinical textbook, remarking that from the way Thomson had operated, he was not surprised that the presence of hydrochloric acid had escaped him. ${ }^{87} \mathrm{How}$ ever, it should be noted how little Prout made of his discovery in later writings and the extent to which he played down the presence of the acid in the stomach. The acid, he suggested, was formed by galvanism (electrolysis) from blood chlorides. ${ }^{88}$

The original work on digestion ended in 1827 with the Copley Medal-winning paper, 'On the Ultimate Analysis of Simple Alimentary Substances, with some Preliminary Remarks on Organic Analysis'. ${ }^{89}$ This, the last of Prout's purely chemical papers, was read to the Royal Society on I4 June 1827. It was planned to be the first of three papers in which he discussed in turn the three food aliments which he was the first to classify as the saccharinous (carbohydrates), the oliginous or oily (fats), and the albuminous (proteins). ${ }^{90}$ However, only this first paper on the saccharine foods and oxygen combustion analysis was ever published. The latter technique had been perfected after the standard copper oxide method had proved too inaccurate; it involved a return to Lavoisier's direct oxygen combustion procedure and it employed a very elaborate piece of apparatus. As far as is known, Prout's apparatus was not adopted by any other chemist, and within a few years Liebig introduced the simple rapid procedures which are still essentially used today. ${ }^{91}$

Prout was a vitalist who believed that organic materials contained independent existing vital principles or agents superior to, and capable of controlling

\footnotetext{
84 i.e. the proof as actually published in Phil. Trans.

85 Ann. Philos., 1824, 24, 68-9. A decade later, Braconnet found $\mathrm{HCl}$, but no lactic acid, in the stomach juice of a dog. The most famous confirmation came from Beaumont in America, but he was never cited by Prout in his later work.

${ }^{86}$ Brit. Ass. Reports, 1839, p. 58, and Phil. Mag., 1845 (3), 26, 323, 418-24.

87 On Stomach, pp. $465,470$.

88 Chemistry, pp. 495-6.

89 Phil. Trans., 1827 , pp. $355-88$.

$90 \mathrm{He}$ usually referred to four alimentary principles-water was the other.

91 It seems that the thermochemist, Hess, may have combined Prout's and Liebig's apparatus for analysis, Brit. Ass. Reports, 1839 , p. 57.
} 


\section{W. H. Brock}

and directing, the forces operating in inorganic matters'. ${ }^{92}$ The four alimentary principles, water, saccharines, fats and albumines, were able to combine together, or in emergencies even transform one into the other, under the influence of organic agencies. ${ }^{93}$ Like Liebig later, Prout urged that a satisfactory diet should include all four foodstuffs and be modelled upon the great alimentary prototype - milk. God had designed a system of 'universal voracity' ${ }^{94}$ whereby lower organisms converted the essential organic elements $(\mathrm{C}, \mathrm{N}, \mathrm{O}, \mathrm{H}$, etc.) into the four proximate principles. This was a 'cuisine obligée for the wants of the higher' organisms, ${ }^{95}$ since by preying on lower animals they found materials already assimilated to their own structures and were thus saved the trouble of creating them.

Prout divided metabolic processes into primary and secondary assimilation, and the third edition of his urine textbook was concerned with the pathology of these actions. Primary assimilation included the processes of digestion and sanguification; secondary assimilation-Liebig's 'metamorphosis of tissues'included both the processes of tissue formation from the blood (formative process) and the destruction and removal of unwanted parts from the animal system (destructive process). As a result of his molecular speculations, Prout laid great stress on the role of water in assimilation. ${ }^{96}$ Materials which contained small proportions of the elements of water were referred to as strong or high; others, usually substances of a more unstable character which contained large proportions of the elements of water, were called weak or low. The conversion of strong into weak substances by the absorption of water was described as reduction, and Prout believed that this was the principal chemical feature of digestion. Once the chyle entered the lacteals, however, the opposite chemical process of completion occurred whereby the aliments were raised from the weak to the strong state and poured into the blood-stream. Here, any combined water was released during the respiratory process. The whole scheme was very ingenious, but naturally Prout was unable to give many details. In any case he did not believe that the processes of reduction and completion were simply chemical; vitalizing agents were supposed to be present in both the stomach and the lacteals. Organization could not occur without the presence and admixture of 'foreign parts'-that is, elements other than the traditional organic elements of carbon, hydrogen, oxygen and nitrogen, or the addition or subtraction of water. Prout had first made this point in $1817,4^{46}$ and in 1827 he coined the word merorganized or merorganization to describe the isomerism and vitalization of organic materials. ${ }^{97}$

By these incidental matters . . . the ordinary chemical properties of the essential elements of the organized living structure are variously modified; in particular, that the essential elements are hindered from assuming a regular crystallized form. Moreover, these incidental matters

\footnotetext{
02 On Stomach, p. 452.

98 Like the archei of van Helmont, these agents seem analogous to enzymes; however, Prout intended that no chemical interpretation should be placed on them. The possibility of a transmutation of matter into calcium was suggested by Prout, Phil. Trans., 1822, p. 377; and into nitrogen, Chemistry, p. 500 .

${ }^{24}$ Chemistry, p. 472.

${ }^{\circ}$ Anon., Quart. Rev., 1839, 65, 329.

${ }^{\circ}$ Holmes, F., Elementary analysis and the origins of physiological chemistry, Isis, I963, 54, 50.

97 The word was coined by a Mr. Lunn (the engraver?). The abstract, Proc. roy. Soc., 1815/30, 2, $324-6$, uses the word protorganized.
} 


\section{The Life and Work of William Prout}

entering into the composition of a living body apparently furnish the organic agent new powers utterly beyond our comprehension.

Daubeny thought merorganization an attractive way to explain some kinds of isomerism, ${ }^{98}$ but no other chemist or physiologist adopted the word; and Prout dropped it-but not the concept-after I 831 .

\section{Meteorology}

Prout designed and constructed (probably with the help of John Newman, the instrument-maker) an expensive barometer some time prior to 1830 . This instrument was highly praised by the meteorologist James Forbes ${ }^{99}$ who thought it 'one of the finest philosophical instruments I have ever had the pleasure of seeing'. Prout's son, the Rev. Thomas Jones Prout, presented it to the Oxford Museum in $1860,{ }^{100}$ but its present whereabouts is unfortunately not known. In 1835 the Royal Society decided to commission a new standard barometer from John Newman who had built the Daniell standard barometer in $182 \mathrm{I}$, and this instrument appears to have been modelled upon the barometer of Prout who was made responsible for its effective construction. ${ }^{101}$ It was completed in 1836 , but Newman's bill evidently shocked Council, for they referred it to Prout for comment. Prout replied that the bill was not unreasonable; ${ }^{102}$ from published accounts the total cost was close on E70. Like Prout's own barometer, the Royal Society's instrument has also disappeared.

Prout appeared in the role of meteorologist at the British Association meeting at Oxford in 1832 when he read a paper summarizing his observations on the specific gravity of air, and the law of expansion of air. ${ }^{103}$ The paper is interesting not only for its precision, but also for one extraordinary observation which had led Prout to make an equally extraordinary speculation. Atmospheric air in both dry and moist states had been weighed daily at noon free from carbon dioxide from December I831 until March I832. His mean value from eighty-six experiments was that $100 \mathrm{cub}$. inches of air, barometer 30 inches, temperature $32^{\circ} \mathrm{F}$., London latitude, weighed $32.795^{8}$ grains ( $\left.\pm 0.05^{\circ} 7\right)$. However, a strange event had occurred on 9 February 1832 :

... on which day the weight of the air was 32.8218 : and it is remarkable that after this period, during the whole time that the experiments were continued, the air almost uniformly possessed a weight above the usual standard; so that ... the mean of the 42 observations after this crisis $(32.8018)$, exceeds the mean of the 44 preceding it $(32 \cdot 7900)$ by no less than 0.0118 grains. The apparatus employed, and the care taken were the same throughout, and there can be no doubt that the difference, whatever it depended on, really existed, and did not arise from error of experiment. ${ }^{104}$

98 Daubeny, C., Introduction to the Atomic Theory, Oxford, 1831, pp. 79-82.

90 In a review of meteorology before the British Association at Oxford, Brit. Ass. Reports, 1832, p. 226.

100 Gunther, R. T., Early Science in Oxford, Oxford, 1923, vol. 1, p. 247, item 194, 'Barometer in University Museum. Facsimile of the Standard Barometer, constructed by the late Dr. Wm. Prout, F.R.S. Presented by the Rev. J. I. (sic) Prout, M.A., Student of Christ Church, I86o.' In fact, the Standard Barometer was a facsimile of this.

101 In a letter to Lubbock, Io March 1835, Prout agreed to oversee the progress of the instrument, but he made it clear that the Royal Society should trust Newman to handle the matter competently by himself (Roy. Soc., MC2 I64). Prout determined the sp. gr. of the mercury to be used. The instrument was fully described by Baily, F., Phil. Trans., 1837, pp. 431-41.

102 Letter to Baily, 25 November 1836 (MC2 232).

${ }^{103}$ Brit. Ass. Reports, 1832 , pp. 570-75.

104 Ibid., pp. 572-3. 


\section{W. H. Brock}

With his typical flare for generalization, Prout wondered whether this anomaly was in some way connected with the terrible cholera outbreak.

It may be worth while to observe that almost precisely at the period above mentioned, the wind veered round to the north and east, where it continued for a considerable time, and that under these circumstances the epidemic cholera first made its appearance in London. It would seem therefore, as if some heavy foreign body had been diffused through the lower regions of the atmosphere about this period, and which was, some how or other, connected with the disease in question. ${ }^{105}$

Even Berzelius was impressed by this argument, for he observed that if a lesser analyst than Prout had suggested it, it would not have deserved consideration. ${ }^{106}$ Prout remained particularly fond of this speculation since he repeated it in his Bridgewater Treatise and in the later editions of his clinical textbook. ${ }^{107}$ Daubeny thought it a fine example of Prout's 'power of generalization' and recalled with what scientific caution he had proposed it.

Although he was understood to have continued the meteorological researches alluded to during the whole period of the cholera in 1832 , he delayed their publication until they could be still further corroborated. Unfortunately, when the cholera broke out a second time in 1848 , his health was too enfeebled to allow of his undertaking, in addition to a large medical practice, a similar course of laborious investigations, so as to satisfy his own scrupulous mind as to their truth. ${ }^{108}$

In another train of argument Prout reasoned that there should be some variation of the specific gravity of air due to wind direction. Air which had travelled over the whole extent of London from the East to his house in the West End (i.e. an east wind) would probably have had a considerable quantity of oxygen removed and replenished by carbon dioxide. Since Prout removed carbon dioxide before making his measurements, it followed that air from the east would 'be necessarily found lighter'. Such differences were small, he admitted, yet his measurements did seem to confirm that air from the east after travelling across populated London did contain a fraction of a per cent less oxygen than air from other quarters. The argument, although correct, could hardly have been significantly demonstrated from such a small number of experiments, especially when the differences involved were no greater than the likely experimental errors.

At the same meeting of the British Association, Prout was elected to the Chemistry Committee, ${ }^{109}$ and a paper on atomic weights was read by Edward Turner. At Cambridge the following year, there was a further paper from Turner ${ }^{110}$ who helped over certain analytical difficulties by Prout was very critical of Thomson's analyses, and his new results did not confirm Prout's

\footnotetext{
105 During 1832 every London physician was puzzled for an explanation of the cholera. Prout's observation was mentioned in the review, Henry, W. C., Laws of Contagion, Brit. Ass. Reports, 1834, p. 92. For a reinvestigation and confirmation during the 1854 cholera season, Thomson, R. D., ibid., 1855 , pp. $71-3$.

106 fahres-Bericht, $1834,13,52$; quoted Benfey, op. cit., ref. 5 .

107 Chemistry, pp. 351-3; On Stomach, pp. 19-21.

108 Edinb. new Phil. F., 1852, 53, 101.

100 Brit. Ass. Reports, 1832 , pp. 113 , 116.

110 Brit. Ass. Report, I833, p. 400; Phil. Trans., 1833, p. 523.
} 
hypothesis. Probably as a result of this, the Chemistry Committee awarded $£ 5^{\circ}$ to Dalton and Prout for the investigation of atomic weight values and specifically to test the integral weight hypothesis. ${ }^{111}$ Nothing is known of this intriguing collaboration. Although Prout's name disappeared from the Committee in I834, he was charged with Dalton and others in the same year to investigate chemical nomenclature and formulae-then a bone of contention among English chemists. ${ }^{112}$ The brief majority report which appeared in 1835 supported the continental nomenclature; ${ }^{113}$ in minority, Dalton urged his own pictorial system. Although Prout would not have adopted this pictorialism, there is no doubt that he agreed with Dalton that the Berzelian formulae were clumsy and unphilosophical.

Prout interested himself in all the sciences which could be aided by chemistry. We have seen him in the roles of chemist, physiologist, physician and meteorologist; in 1829 he briefly filled the role of geochemist. His two geological analyses of bezoar stones and coprolites were undertaken at the request of William Buckland who presented the results to the Geological Society. ${ }^{114}$ Both these analyses were connected with Prout's physiological work, especially that of coprolites which he showed consisted of large amounts of calcium phosphate, and confirmed Buckland's opinion that it was a fossil faeces.

\section{The Gulstonian Lectures of $183 \mathrm{I}$}

Prout, who had been elected a Fellow of the Royal College of Physicians on 25 June 1829 , was appointed to the 183 I Gulstonian lectureship. His three lectures on 'The Application of Chemistry to Physiology, Pathology and Practice'115 were a continuation of the theme of the 1827 Copley paper, and anticipated the third Book of the Bridgewater Treatise. Prout suggested that the physiologist of his day paid too much attention to mechanical or even metaphysical explanations in biology, whereas for him biology called for the application of chemistry. There had been a certain lack of success in animal chemistry, both because of the intrinsic difficulty of the subject and through the incompetence and incomprehension of the pure (i.e. inorganic) chemist when he had begun to work in the unfamiliar field of biology. Prout's plea for progress was: physiologists become chemists. ${ }^{116}$

In conjunction with the phenomena presented by living organized bodies with which he ought to be thoroughly acquainted, he must carefully study their common chemical properties, their ultimate composition, the laws of their formation and change, and a multitude of other matters which the mere chemist is apt to overlook, or knows not how to appreciate even if he observes them.

The elements of organized substances were the very same as those of inorganic materials, and it was totally unnecessary to suppose that an organic principle

\footnotetext{
111 Brit. Ass. Reports, 1833, p. xxxvi. Later Prout and Thomas Clark, Prof. of Chemistry at Aberdeen, were awarded $f_{40}$ for sp. gr. measurements, ibid., 1839, p. xxix.

112 Brit. Ass. Reports, 1835 , p. xxv.

113 Brit. Ass. Reports, 1835, p. 207; Daubeny, ibid., 1836, p. xxxiv.

114 Geological Soc. Proc., I834, I, 139 (read 1829); Geol. Soc. Trans., 1835, 3, 237-40 (read 1829).

115 Med. Gaz., 1831, 8, 257-65, 321-7, 385-91.

116 Ibid., p. 258. He had anticipated this in 1816, Ann. Med. Surg., p. 289; cf. also ref. 25.
} 


\section{W. H. Brock}

held these elements together when the ordinary observed chemical affinities of one element for another was quite a sufficient explanation. At this level at least, vitalism was superfluous. Yet it was a fact that organic materials differed fundamentally from inorganic substances, and here Prout reintroduced the idea of merorganization whereby minute quantities of 'impurities' performed 'an office which may be termed interstitial - that is to say, that they operate by being interposed, as it were, between the essential elementary atoms of organized substances, and thus prevent them from assuming the crystallized form, in which stage they would be totally unfit for the purposes of the economy of living organized beings'. ${ }^{117}$ Organic agents were then introduced to attend the design of merorganization.

Chemistry was both a science and an art (i.e. technology), but as a theoretical science it was little understood, and Dalton's atomic theory by stopping where it had, had retarded chemistry rather than advanced it, 'for to suit the imaginary standards of this bed of Procrustes, real results, I fear, have been too often extended or compressed beyond all legitimate bounds and thus truth sacrificed to error'. ${ }^{118}$ This statement came ironically from Prout whose own unitary hypothesis had led a devoted Thomson close to doing just that. What Prout meant-and he should have been explicit-was that the classic atomic theory of Dalton had stopped short of the molecular concept and therefore, in his opinion, it had hindered the progress of pure chemistry. In any case his commitment to a reduction in the number of elements had also led him to a positivist position that the atomic theory was only a 'conventional artifice'; atomic or equivalent weights were really only single terms in an arithmetical series peculiar to each substance. 'Thus 9, the number assumed to represent the combining weight of water, is to be considered as one term of the series $3: 6: 9: 12: 15$, \&c., in all which proportions (and perhaps in still lower submultiples of them) this fluid enters into combination, perhaps quite as often as in the proportion 9, especially in the organic kingdom.'119 This crude foreshadowing of valence was fully exploited in the Bridgewater Treatise where the digestion and assimilation of foodstuffs were explained by a sort of Pythagorean number mysticism. ${ }^{120}$

The three Gulstonian lectures were printed in pamphlet form for private circulation and favourably reviewed in the Medical Gazette, ${ }^{121}$ except for a note of rebuke sounded over Prout's professed dislike of Daltonian atomism. However, the lectures were not received so sweetly by the physiologist Wilson Philip, who strongly objected to Prout's suggestion that there had been almost no progress in physiology in twenty years. Characteristically, in a reply, Philip catalogued his own achievements at great length and detail. ${ }^{122}$ An answer from Prout was followed by a rejoinder from Philip, and so began a dispute concerning the place of chemistry in physiology in which knocks were given and taken on both sides. ${ }^{123}$ Dr. McMenemey has observed that 'this acrimonious correspondence reveals surprising shortcomings in the mind of Wilson Philip, a man who in his earlier days was obviously a thinker. He was, it seems, entirely

\footnotetext{
117 Med. Gaz., 1831, 8, 260.

120 Chemistry, pp. 480 et seq.

121 Med. Gaz. $1831,8,468$.

110 Ibid., p. 263.

122 McMenemey, W. H., J. Hist. Med., 1958, 13, 314.

123 The row may be followed intermittently through $\mathrm{Med}$. Gaz., 1831, 8, and 1831/2, 9.
} 


\section{The Life and Work of William Prout}

oblivious to the possibilities of clinical and especially chemical pathology in the practice of medicine.' ${ }^{122}$ Ironically, it appears that by the 1840 , the vitalist Philip had come round to Prout's viewpoint completely, even to the extent of claiming it as his originally (e.g. that the nervous system was essentially chemical). Prout, on the other hand, had become more deeply committed to vitalism, as another Gulstonian antagonist, the Manchester surgeon, John Roberton, had predicted. Roberton objected to the implied vitalism of the term organic agent, and argued that it calculated 'by its mysticalness to retard or discourage the study of this science'. ${ }^{124}$ However, Prout refused to be drawn into any argument over vitalism.

\section{The Bridgewater Treatise ${ }^{\mathbf{1 2 5}}$}

The eighth and final Earl of Bridgewater, who died in 1829 , bequeathed $£ 8,000$ to the Royal Society as a payment to the person or persons chosen by its President who would

write, print and publish, rooo copies of a work on the Power, Wisdom and Goodness of God as manifested in the Creation; illustrating such work by all reasonable arguments, as for instance the variety and formation of God's creatures in the animal, vegetable and mineral kingdoms; the effect of digestion, and thereby of conversion; the construction of the hand of man, and an infinite variety of other arguments. ${ }^{126}$

Prout was one of the eight authors chosen by the President of the Royal Society, Davies Gilbert, and his numerous advisers. The Chemistry, Meteorology and the Function of Digestion with Reference to Natural Theology appeared in $18344^{127}$ As we have seen, Prout was well qualified to write with originality on the diverse topics included in the title; however, in 1854 when the agnostic physicist John Tyndall was asked to edit this Treatise for the popular Bohn Library series, his sarcastic private comment was:

I should have thought more highly of Dr. Prout had I not read his book. Certainly if no better Deity than this can be purchased for the eight thousand pounds of the Earl of Bridgewater, it is a dear bargain. It is very evident that Dr. Prout would never have written such a book through the spontaneous promptings of his own spirit; it was written for money, and lacks even common scientific depth, not to speak of religious inspiration. ${ }^{128}$

Tyndall was unfair in his estimate of the book's scientific standard, for many of its pages had simply dated. Possibly there was something in the financial sneer, though this was a common criticism of all the Treatises' authors, for we have Munk's report that 'in pursuing his scientific investigations, and especially those on the atmosphere, expense was not regarded by Dr. Prout, and much of his apparatus was of the most elaborate and costly character' ${ }^{129}$ In addition, Prout

124 Med. Gaz., I831, 8, 745. Later, after Prout's Bridgewater had appeared, Roberton attacked his vitalism in Critical Remarks on certain recently published opinions concerning Life and Mind, 80 pp., 1836 (not seen).

${ }_{125}$ Brock, W. H., Prout's Bridgewater Treatise, 7. Chem. Educ., 1963, 40, 652-5.

186 Prout, W., Chemistry, publisher's announcement, p. vii.

127 The eighth Bridgewater Treatise, London, Wm. Pickering, two eds. May and June 1834,3 rd ed. enlarged $1845,4^{\text {th }}$ ed. posth. 1855 (ed. J. W. Griffith).

128 Tyndall's private journal, I9 November 1854 , in the Royal Institution. Tyndall was perhaps disconcerted by Prout's vitalism.

129 Munk, op. cit., p. I I (from Med. Times, p. I 7), 


\section{W. H. Brock}

had his family to support with children at Westminster School and later at Oxford. No doubt then the Bridgewater legacy was very welcome.

The theological content of Prout's treatise followed the pattern of its companions; examples of apparent utility and design in both the inorganic and organic kingdoms were, by cumulative effort, made an argument for the unity of design and purpose and beneficence of a Superior Chemist. Munk, when he wrote in 1878 after the argument for the existence of God from Design had received hard knocks from the evolutionists, still described the book as 'a work of high merit and of much originality'. Indeed, in my view the work was the most daringly speculative of all the Bridgewater Treatises and consequently, perhaps, the least successful in sales. Daubeny considered that Prout showed 'much ingenuity in unravelling the mysteries which beset us when we attempt to speculate on the intimate constitution of matter. While soaring into this elevated region, he caught a glimpse of those views respecting the distinction between physical and chemical atoms, from the development of which Dumas has since derived so much celebrity'. ${ }^{130}$ This distinction-really that between molecule and atom-was the subject of a controversy between Prout and the Daltonian, William Charles Henry. In a letter to the Philosophical Magazine, ${ }^{131}$ Henry objected to Prout's version of Dalton's atomic theory, in particular the doctrine that equal volumes of gases under the same conditions contained the same number of atoms-an opinion which Dalton had outrightly rejected. Henry also repudiated, as had Dalton, the logical corollary that the 'atom' (i.e. molecule) was divisible, or as Dumas and Gaudin had put it, that there was a distinction between the chemical and physical atom. Prout replied characteristically with a short letter ${ }^{132}$ in which he refused to debate the subject, but he implied that he had held such ideas from 1815. It is very unfortunate that Prout did not seek to justify his molecular viewpoint at greater length in such an important journal as the Philosophical Magazine, for although the Bridgewater went through four editions, it must be assumed that its attraction for readers was as a book of apologetics rather than as a chemical textbook. Thus its readership would have been lay rather than scientific; the only chemist who seems to have been at all influenced by Prout's molecular views was his friend Charles Daubeny. Consequently, although like its companion volumes, Prout's treatise is no longer read, and scientists and historians associate Prout's name with the unitary hypothesis, at the time of his death it was recalled that 'he was deservedly known to the public generally by his various contributions to the advancement of medical science, particularly by his Bridgewater Treatise'. ${ }^{133}$

\section{5-50, Clinical work, death and character}

Nothing has come to light of Prout's clinical career and practice during the remainder of his life. A third edition, or rather a completely new version of his 'magnum opus', On the Nature and Treatment of Stomach and Urinary Diseases

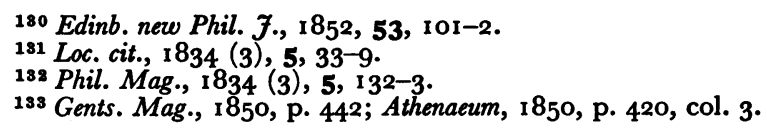




\section{The Life and Work of William Prout}

appeared in September $1840,{ }^{134}$ but the book's interest is diminished for the historian of science by Prout's practical bias and lack of theoretical challenge. Indeed, as edition followed edition, even contemporary reviewers criticized Prout for not examining and explaining some of the theoretical issues involved in physiology. ${ }^{135}$ Today the most interesting section of the book is the introductory first part with its succinct account of the physiology of the digestive and urinary systems-much of it a specialized version of material previously presented in the third Book of his Bridgewater Treatise. Yet, in the two subsequent editions Prout unwisely placed this section at the end of the volume as a third Book, and so further emphasized the work's practical bias. It was, however, impossible to understand the first two Books which employed Prout's special vocabulary and nomenclature, without first referring to the third Book!

Although as one obituarist said the ideas in this work 'excited by their novelty, considerable attention, but do not seem to have made the impression their importance deserved', ${ }^{136}$ Prout himself was really to blame for the neglect and ineffectualness of his studies. He was inherently a conservative man and he consequently suffered the chagrin of living to see Liebig and other continental chemists and physiologists build a science on many of the principles which he had stated or foreshadowed. Thomas Wakley, in a Lancet editorial, ${ }^{137}$ made a personal attack on Prout's inertia and conservatism in 1844 which went directly to the heart of the matter. This was the period when ardent efforts were made to woo Liebig into an English Chair of Chemistry in order to stimulate the teaching and study of the subject in this country. A patriot had asked Wakley why England needed a Liebig when they already had a distinguished chemist in Prout. That was just the trouble, argued Wakley: 'Many individuals hold Dr. Prout to be the first of British organic chemists; but several of the doctrines he espouses are opposed to those which are now taught in the continental schools that possess the highest repute.' One had only to read the 1843 edition of Prout's Urinary Diseases to see this. For instance: Prout had ignored the discovery of pepsin and relegated the views of Schwann and Müller to a brief footnote; he had old-fashionedly stated that exact compositions of albuminous substances could not be given, and he still regarded them as compounds of just four elements 'merorganized' by minute portions of certain 'incidental minerals'; he had completely ignored Mulder's proteine; he more or less ignored Liebig's argument for the progressive changes of organic compounds in the living state, and questioned the accuracy of the analyses upon which such views were based; finally, Prout never referred to the action of oxygen on tissues,

\footnotetext{
184 ard ed., 1840, 483 pp. with set of plates showing urinary deposits viewed through a compound microscope. Reviewed, Brit. for. med. Rev., 1841, II, 330-64; $4^{\text {th }}$ ed., 1843, 593 pp., reviewed ibid., 1843 , 16, 477-86; 5 th ed., 1848, retitled On Nature ... Stomach and Renal Diseases, 595 pp., reviewed Edinb. med. surg. F., 1848, 70, 419-53.

135 e.g. Brit. for. med. Rev., 1841, II, 336: 'Dr. Prout assumes to himself merit for "avoiding all controversial points", but he means the discussion of these; so far from avoiding such points . . . he settles them invariably ex cathedra, without the least apparent misgivings as to the rectitude of his decisions. However grateful it may be to some readers to meet with a conviction so strong that it almost displays itself in dogmatism, we for our part, feel persuaded that it diminishes the real usefulness of the volume.'

${ }^{136}$ Med. Times, $1850,1,17$.

187 On the labours of Prout, Lancet, $1844, \mathbf{i}, 486-90$.
} 
whereas Liebig and Wöhler based all their studies upon the concept of tissue oxidation. This was a formidable list of justified complaints, and Wakley was in little doubt of the reasons for Prout's own failure. (I) Prout had declined to use chemical formulae which he scorned as unphilosophical expedients because they did not represent true compositions. Although we can see how Prout was placed in this position by his molecular theories, we must agree with Wakley that this showed a disastrous inability on Prout's part to keep pace with the development of science. (2) Prout deserved his reputation, but as an historic figure, for his work on gastric juice and the alimentary principles. No doubt continental chemists had begun where Prout left off. But why had it been left to them? Because 'Dr. Prout's name and authority exercises an influence that is detrimental' to the teaching and progress of chemistry in Great Britain. Science declined when 'the authority of those who, having earned a reputation for themselves, cast unfounded doubts upon the labours of others, neglect and repudiate, without sufficient cause, the methods followed by their competitors, and deny them that honour to which they are justly entitled by their discoveries. We regret to find Dr. Prout in this category. ${ }^{.138}$

Prout seems to have made no reply to these criticisms but a few changes were made in the fifth and final edition of his textbook which appeared in 1848 . However, its lack of chemical formulae and distillation of continental work led to its rapid replacement by other texts, notably that of Golding Bird. ${ }^{139}$

Deafness afflicted Prout long before his death, and this caused him to withdraw from scientific society - to its loss, and perhaps even more so to his. Thus there is no mention of him at the Royal College of Physicians after 1834, or at the Royal Society after 1836 , or at the British Association after 1839 . He fell ill in 1848 , and became worse in the summer of the following year. An autumn excursion into the country did not improve his health, and, emaciated, he returned to London to continue with his practice. His health grew worse in the spring of 1850 , and when the President of the Royal Society, the surgeon, Sir Benjamin Brodie, called to see him on the 9 April, Prout told him that he knew that he was dying. The end came the same day; the cause apparently gangrene of the lung following a burst abscess. He had requested that no postmortem should be made. Prout is buried somewhere in Kensal Green cemetery, and there is a simple memorial tablet in Horton village church which records:

Sacred to the Memory of William Prout, M.D., F.R.S.

Born in this parish 15 January 1785

Died in London 9 April 1850

Scintillulam contulit

Prout was an early riser who did some of his own work before he breakfasted at 7 a.m.; the remainder of the day was devoted to his patients. 'Besides his extensive town practice, scarcely a day passed that boxes and parcels did not arrive from the country, and the analyses of their contents, together with the

188 Lancet, 1844, i, 490.

130 Bird, Golding, Urinary Deposits, their Diagnosis, Pathology and Therapeutical Indications, 1844, 3rd ed., $1851,4^{\text {th }}$ ed. $1853,5^{\text {th }}$ ed. 1857 . Bird owed much to Prout with whom he was on excellent terms. 


\section{The Life and Work of William Prout}

necessary correspondence, consumed no small portion of each day. ${ }^{136}$ There are also references to an extensive foreign correspondence, but no trace of this has come to light. Deafness must have been especially tragic for him since he had a great love of music. At some time in his life he built an organ 'which he played with great skill; several anthems were also composed by him'136 presumably strictly for family consumption. He possessed a similar love for painting, and his consulting rooms were hung with several canvases.

A notable estimate of his character has been quoted at the head of this essay. Prout undoubtedly impressed those with whom he came into contact. Thus Thomas Thomson thought most highly of him, and W. G. Henry, who disagreed so profoundly with Prout's interpretation of the atomic theory, admitted that like Wollaston and Davy, Prout possessed 'a taste for extreme exactitude' and an 'unrivalled manual expertness' never achieved by Dalton. ${ }^{140}$ The highest praise came not unexpectedly from Prout's great friend, Daubeny: Prout was 'a great original thinker as well as an accurate and scrupulous experimentalist'. ${ }^{141}$

\section{Iconography}

The following general description of Prout is recorded:

He was of middle height, and of slim figure. His head was nobly developed, and the intellectual qualities strongly marked; the hair soft and snowy white. His features were delicately chiselled, eyes brilliant, complexion very pale, but the expression of his countenance combined benevolence with great intelligence. There was a blandness in his manner which inspired confidence, and set the most nervous patient at ease. He always dressed with scrupulous neatness, usually in black, with gaiters, or silk stockings. ${ }^{142}$

Of Prout's portraits, three of four known canvases have been traced. A lost portrait in oils painted by John Hayes, a pupil of David, was executed during the 1830 . This portrait undoubtedly remained in the possession of the family until at least as late as 1909, but it has not proved possible to discover its present location.* A copy of the Hayes was made by Henry Wyndham Phillips for the Royal College of Physicians in 1855,143 and until recently this hung on the main stairway of the College's premises in Pall Mall. Prout's youngest son, the Rev. Thomas Jones Prout, Scholar of Christ Church, Oxford, was most dissatisfied with the Phillips portrait, and in a letter to the Royal College ${ }^{144}$ he offered them a new reproduction of the Hayes by $H$. M. Paget. 'It will certainly be more satisfactory to ourselves, as well as to those who may remember our Father and to any others who may care to know what he was like, that the College possess a picture which does recall him better than the portrait which hangs on their walls at present.' This new portrait was presented to the College by Prout and his sister, Elizabeth, in June 1888 . 'I venture to ask for it a place on the

* Since writing this article $I$ have discovered the location of this portrait. But permission to reveal the owner's name has not yet been obtained.

140 Henry, W. C., Life of John Dalton, 1854, p. 230.

141 Edinb. new Phil. $\mathcal{7}$., 1852, 53, 101.

142 Med. Times, 1850 , 1 , I 7 , quoted Munk, p. I 13.

148 Wolstenholme, G. (ed.), The Royal College of Physicians Portraits, London, Churchill, 1964, p. 346. A note by Munk intended for a later ed. of his Roll records that on 20 February 1855 , Phillips was given $\mathrm{f}_{50}$ for the portrait and frame. But a letter in R.C.P. from Sir Thomas Watson to Dr. Farre, 24 December 1873, reports that Phillips had been surprised to be paid in guineas, not pounds.

${ }_{144}$ To Sir Henry Pitman, 5 May 1888 (R.C.P.). 


\section{W. H. Brock}

walls of the College, not as being entirely satisfactory, but as being a decidedly better likeness of my father than that which has hitherto hung there.'145

The existence of the miniature mentioned by Philip Hartog in his Dictionary of National Biography notice of Prout is doubtful.146 Thomas Prout stated that he had never seen or heard of it before.

In 1902 Thomas and Elizabeth Prout commissioned a second copy of the Hayes from Paget for presentation to Edinburgh University, ${ }^{147}$ where it now hangs on the Secretary's Staircase. Finally, Thomas had photographs made of the Hayes original. A photograph was given to William Osler some time in 1905, and this is now at McGill's Osler Library. ${ }^{148} \mathrm{~A}$ similar photograph was presented to the Chemical Society in $1904,{ }^{149}$ though their present copy appears to be a later print.

\section{ACKNOWLEDGEMENT}

I am grateful to the Librarians of the Royal College of Physicians, the Royal Society of Medicine and the Royal Society for their help during this research.

\footnotetext{
145 To Pitman, 19 June 1888 (R.C.P.). Ironically the College has always displayed the Phillips and stored the Paget. For the striking contrast, see Wolstenholme, op. cit., p. 348.

${ }^{146}$ Watson reported in his letter to Farre that Phillips did his portrait from 'a small miniature in the possession of the family'. Munk, who was responsible for establishing cordial relations between Thomas Prout and the R.C.P., asked him about the miniature's provenance. (This was after Munk had mentioned it in the Roll.) Prout replied that he knew nothing of it. 'If therefore Mr. H. Phillips had such a miniature, it was either his own property inherited from his Father who was an old friend of our Father's, or, if it was our property, Mr. H.P. omitted to restore it.' (To Pitman, 5 May 1888.)

${ }_{147}$ Rice, D. T., and McIntyre, P., Edinburgh University Portraits, Edinburgh, 1957, p. I 57.

148 Cushing, H., Life of Sir William Osler, 1925, vol. II, pp. 19I-2. I have to thank Cécile Desbarats of the Osler library for tracing the history of this print.

140 7. Chem. Soc. (Trans.), 1904, 85, 480. Reproduced 7. Chem. Educ., 1939, 16, 401.
} 